\title{
Nowe kierunki rozwoju architektury wież mieszkalnych na wybranych przykładach - Manhattan, Nowy Jork
} New trajectories of Residential Tower Development on selected examples in Manhattan, New York

\begin{abstract}
STRESZCZENIE:
Historycznie najwyższymi budynkami Nowego Jorku były budynki biurowe. Ich wysokość to jedna z głównych cech zabudowy na Manhattanie, a wypełniona strzelistymi budynkami sylweta miasta jest rozpoznawalna na całym świecie. W XXI wieku tę sylwetę tworzą także wieżowce mieszkalne. Autor poddaje analizie sytuację i ewolucję budynków mieszkalnych na Manhattanie - budowanych często w miejscach dawnych budynków biurowych. Z badań autora wysuwa się wniosek o istnieniu dwóch kierunków w zabudowie mieszkaniowej XXI wieku w Nowym Jorku. Trend funkcjonalny - polegający na pogłębiającej się hybrydyzacji funkcji oraz trend wysokości - ściśle związany z rozwijającymi się możliwościami technologicznymi, a często pogarszający dostęp do naturalnego nasłonecznienia niższych kondygnacji oraz przewietrzania. Autor, poddając analizie wybrane przykłady budynków, rozważa w jakiej relacji wobec siebie pozostają oba wątki architektoniczne oraz jaki mają wpływ na obraz i kompozycję miasta.
\end{abstract}

\begin{abstract}
:
Historically, the tallest buildings to be built in New York were office towers. Their height is one of the defining characteristics of Manhattan's development, and the city's skyline, filled with towering buildings, is recognisable all over the world. In the twenty-first century, this skyline is also formed by residential towers. We analysed the situation and evolution of housing buildings on Manhattan, buildings that are often built in place of former office buildings. Based on our research, we have observed the existence of two trajectories in the design of twenty-first-century housing in New York. The first is the functional trend and it is based on an increasing hybridisation of function. The second is the trend of height, which is closely linked with developing technological potential, and which often adversely affects access to insolation on lower storeys and to cross-ventilation. We analysed selected cases of buildings and discussed the relationships between these two architectural currents and their impact on the image and composition of the city.
\end{abstract}

Słowa kluczowe: Nowy Jork, wieża mieszkalna, Manhattan, Aleja miliarderów

Keywords: New York, residential tower, Manhattan, Billionaires' Row

\section{WSTĘP, ZAKRES I METODA}

Nowy Jork. Miasto snów, niegasnącego rytmu jazzu, intelektualistów i barów, które nigdy się nie zamykają. Miasto sportretowane w tak wielu filmach i książkach, że wydaje się symulacją tęsknot i nadziei a nie realnym bytem. Nowy Jork to miasto mitycznego sukcesu (tam dopływali opuszczający Europę poszukiwacze nowego szczęścia), bo przecież "jeżeli uda się tam, uda się wszędzie" (fraza z utworu „New York, New York”, komp. John Kander, słowa: Fred Ebb).

Swoistym ucieleśnieniem mitu w ramach przestrzeni urbanistycznej stała się dzielnica Manhattan i pnące się w górę budynki biurowe. Bo historycznie najwyższymi budynkami Nowego Jorku były właśnie budynki biuro-

\section{INTRODUCTION, SCOPE AND METHOD}

New York, the City of Dreams, of constantly resounding jazz rhythms, of intellectuals and bars that never close. It is a city that has been portrayed in so many films and books that it appears to be a simulation of yearnings and hopes instead of something real. New York is a city of mythical success (this is where people who left Europe in search of a better fortune would disembark), for if one can make it there, one can make it anywhere (The phrase 'If I can make it there, I'll make it anywhere' from 'New York, New York', music by John Kander, lyrics: Fred Ebb). Manhattan and its towering office buildings have become an embodiment of this myth within urban 


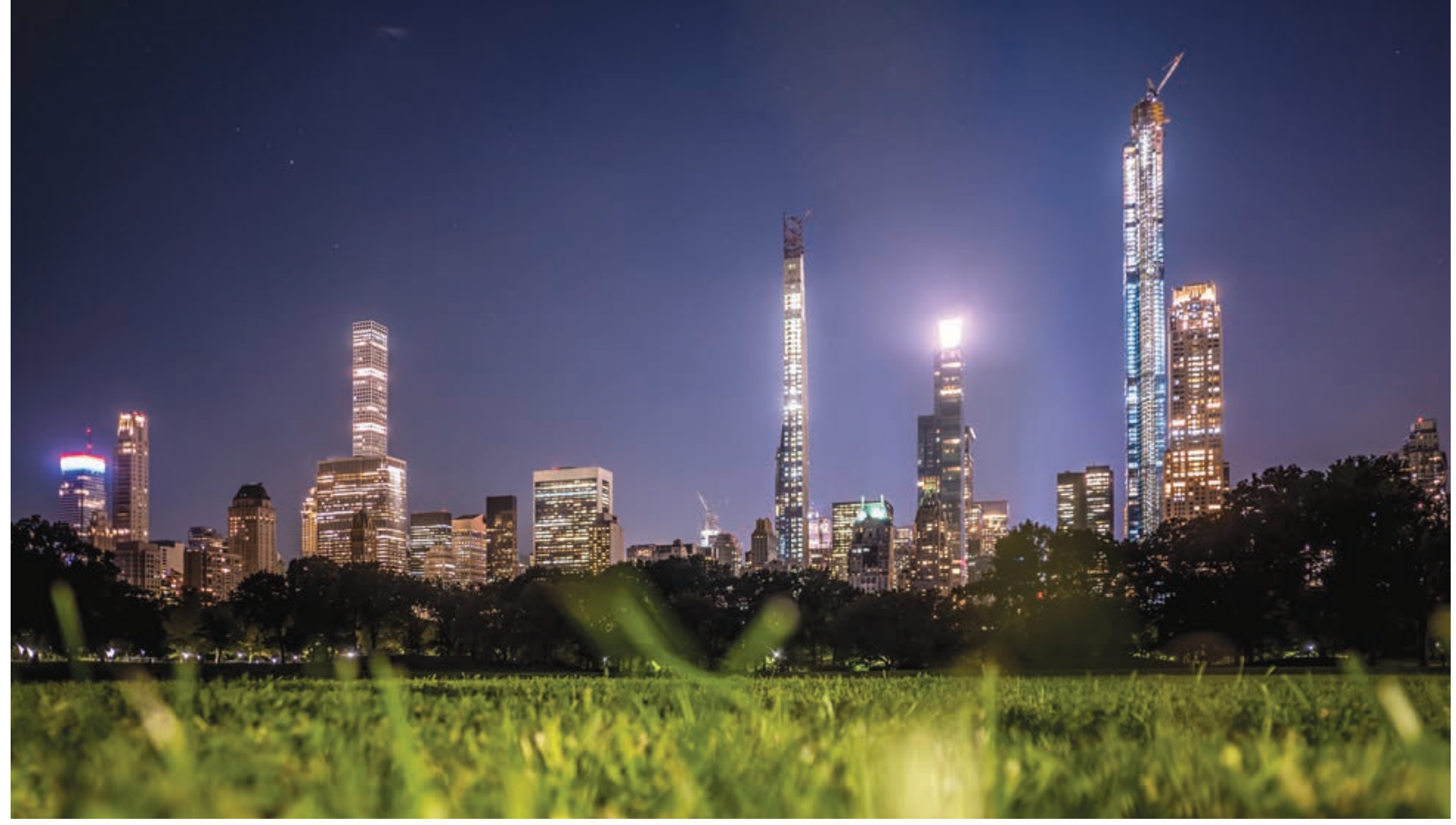

il. 1. Widok na południową krawędź Central Parku z powstającymi wieżami mieszkalnymi, fot. Mariusz Twardowski III. 1. View of the southern edge of Central Park and its newly-built residential towers, photo by Mariusz Twardowski

we - budynek Chryslera (1930), Empire State Building (1931) czy dawne World Trade Center (1973). Upadek Lehman Brothers w 2008, który zapoczątkował finansowy kryzys oraz ruch społeczny \# occupywallstreet (red. Blumenkranz, Gessen, Greif i inni, 2012), okazują się jednak symbolicznym końcem tej epoki i początkiem nowej - postnowoczesnej, hybrydowej, w której miasto wymaga rozwiązań typu smart (Shah, Kothari, Doshi, 2019), a przestrzenie domowe i biurowe mieszają się, a sukces przestaje być mierzony godzinami spędzonymi przy korporacyjnym biurku.

W XXI wieku, sylwetę miasta tworzą także wieżowce mieszkalne. Nowy typ zabudowy, który domaga się uwagi i analizy, zarówno pod kątem urbanistycznym, estetycznym i funkcjonalnym, a także społecznym, choć ta ostatnia nie będzie przedmiotem niniejszego opracowania.

W tekście przedstawiono studium przypadków - do analizy wybrano pięć budynków-wież mieszkalnych wybudowanych w Nowym Jorku wzdłuż południowej granicy Central Parku na Manhattanie w ostatniej dekadzie. Analizie zostają poddane cechy znaczące dla charakteru danej budowli (sfotografowane przez autora podczas wizji lokalnej) i jej wpływ na otoczenie.

\section{Charakterystyka kierunków we współczesnej zabudowie mieszkaniowej na manhattanie}

\subsection{One 57}

One 57 to budynek autorstwa Christiana de Portzamparca (laureata Nagrody Pritzkera z 1994 roku), zrealizowany w 2014 roku w pobliżu Central Parku (157 West 57th Street, między 6th i 7th Avenue, Midtown, Nowy Jork). Architekt zaprojektował 306-metrową, Iśniącą, przeszkloną wieżę. Dzięki przeszkleniom masywna budowla rozprasza się w przestrzeni, odbijając sąsiadujące budynki, a widoki, szczególnie z najwyższych kondygnacji, rozpościerają się daleko poza brzegi rzek Wschodniej space. Historically, it was office buildings that were the tallest in New York: the Chrysler Building (1930), the Empire State Building (1931) and the World Trade Center (1973). The fall of Lehman Brothers in 2008 that began the financial crisis and \# occupywallstreet (ed. Blumenkranz, Gessen, Greif et al., 2012), have turned out to be a symbolic end of one era and the beginning of another - a postmodern, hybrid era in which the city requires smart solutions (Shah, Kothari, Doshi, 2019), residential and office spaces are intermixed and success is no longer measured in hours spent at a corporate desk job.

In the twenty-first century, city skylines are also formed by residential towers. It is a new type of development that requires attention and analysis in terms of urban planning, aesthetics and function, as well as in social terms. This last category is excluded from this study.

This paper presents a case study-five residential tower buildings were subjected to analysis. They have been built in New York along the southern edge of Central Park on Manhattan in the last decade. The analysis covers features that can be considered significant to the character of a given building (which I photographed during a site visit) and its impact on its surroundings.

\section{Overview of trajectories in contemporary Manhattan housing development}

\subsection{One 57}

One 57 is a building designed by Christian de Portzamparc (a 1994 Pritzker Prize laureate), built in 2014 near Central Park (157 West 57th Street, between 6th and 7th Avenue, Midtown, New York). De Portzamparc designed a gleaming, glazed tower with a height of $306 \mathrm{~m}$. Due to its glazed surfaces, the massive building appears to be scattered in space, reflecting surrounding buildings, and the views it of- 
pomieszczeniami konferencyjnymi i rozbudowaną strefą wejściową. Luksusowe apartamenty zaplanowano od 32 do 90 kondygnacji, zaś w części środkowej znalazły swoje miejsca przestrzenie wspólne. Są to $\mathrm{m}$. in. biblioteka, kameralne kino, sale fitness i siłownia, pomieszczenie przeznaczone na imprezy z zapleczem kuchennym. Lokalizacja, doskonałe wykończenie, widoki i zaplecze organizacyjno-usługowe a także prestiż projektanta wpłynęły na rekordowe ceny sprzedaży apartamentów, często kupowanych także pod kątem inwestycyjnym (Goldberger, 2014). W 2014 roku, właściciel Dell Technologies, Michael Dell zakupił penthouse za 100,5mln dolarów. Był to wówczas najdrożej sprzedany apartament w mieście w historii. Dopiero od roku 2018, ze względu na kryzys rynku luksusowych nieruchomości, ceny zaczęły spadać.

\subsection{Park Avenue}

Manhattan, a zwłaszcza Midtown, czyli jego środkowa część, to miejsce, w którym trudno wyobrazić sobie jakiekolwiek puste przestrzenie. Gęstość zabudowy jednak wciąż rośnie, a istotnym elementem każdej pracy projektowej na tym obszarze jest stworzenie koncepcji budynku, który, przy niewielkiej powierzchni zabudowy, zapewni wysoki potencjał eksploatacyjny (Sugar, Kennedy, 2021). Wieżowiec 423 Park Avenue należy do tej grupy. Jak pisał Wojciech Kosiński: „Avenue bije wszystkie dotychczasowe rekordy - będzie najszczuplejszy, najwyższy i zdecydowanie najdroższy" (Kosiński, 2008).

Ukończony w 2015 roku, zaprojektowany przez biuro Rafaela Viñoly (Urugwaj) wybija się i wyraźnie góruje nad pozostałą zabudową Midtown, a także nad rosnącymi
The lower storeys of One 57 house the luxurious Hyatt Park Hotel with a pool, spa, sauna, restaurant, conference spaces and an elaborate entrance zone. Luxury apartments were designed on storeys no. 32 to 90 , while the middle section houses common areas. These include, among others, a library, a cameral cinema, a gym and fitness spaces, a space for events with kitchens. The location, excellent finishes, views and organisational and services infrastructure, in addition to the prestige of the designer, resulted in record apartment sale transaction prices. The apartments were also often purchased as an investment (Goldberger, 2014). In 2014, the owner of Dell Technologies, Michael Dell, bought a penthouse here for $\$ 100$ million. At the time, it was the highest price ever paid for an apartment. The prices began to fall in 2018 due to a crisis on the luxury real estate market.

\subsection{Park Avenue}

Manhattan, and specifically Midtown, its central section, is a place where it is difficult to imagine any empty space. Development density is constantly growing and creating a building that can provide a high operational potential with a small footprint is an essential element of any design (Sugar, Kennedy, 2021). The building at 423 Park Avenue is one such building. As Wojciech Kosiński wrote: 'Avenue has beaten all previous records-it shall be the thinnest, tallest and clearly the most expensive' (Kosiński, 2008).

Completed in 2015 and designed by Rafael Viñoly's design firm (Uruguay), it clearly stands out and towers above the remainder of Midtown's development and the nearby trees of Central Park. Four hundred and twenty-five metres. This is how tall Viñoly's building

il. 4, 5. 432 Park Avenue, proj. Rafael Viñoly, 2015 r., fot. Mariusz Twardowski

ill. 4, 5. 432 Park Avenue, design by Rafael Viñoly, 2015, photo by Mariusz Twardowski

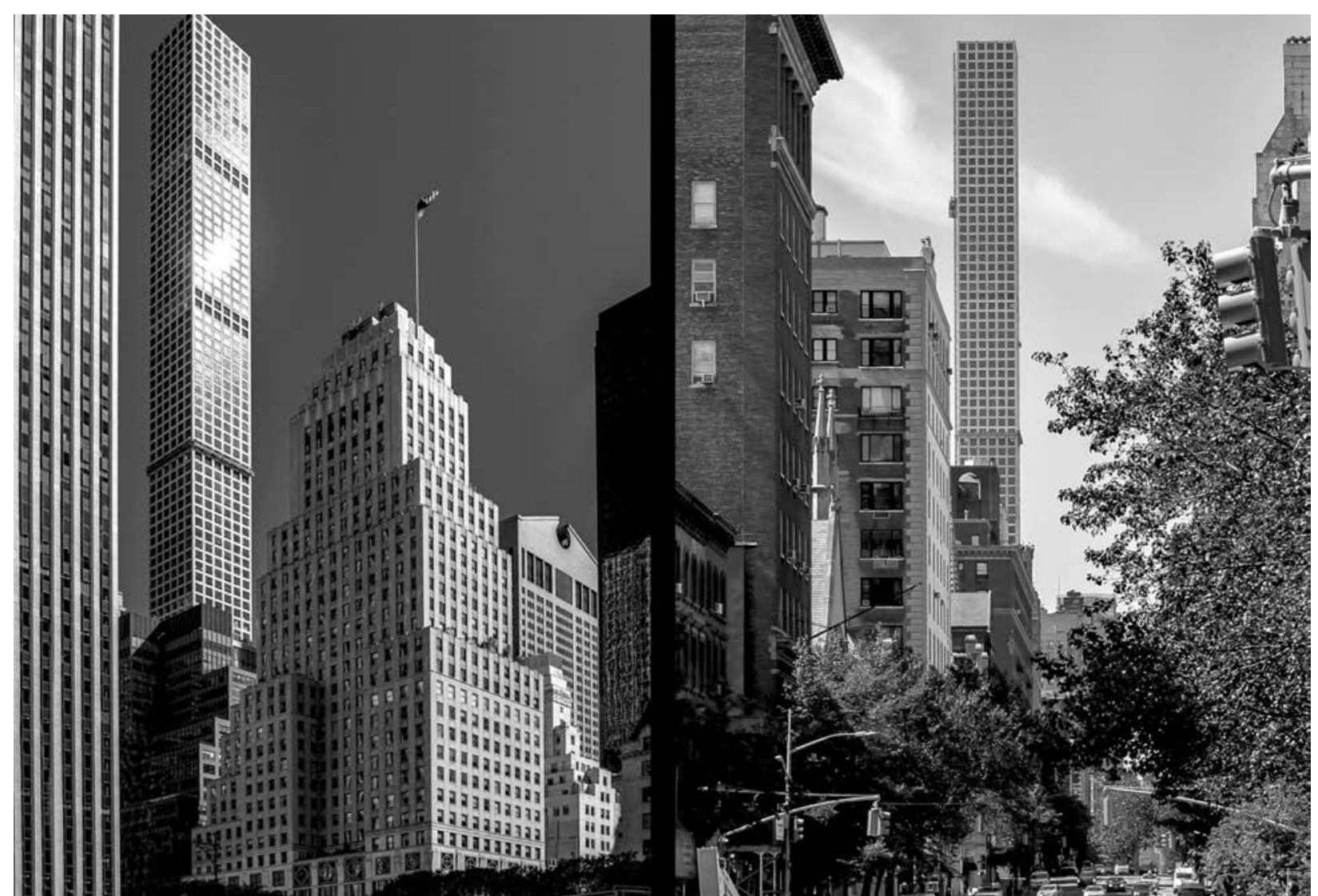


nieopodal drzewami Central Parku. 425. Dokładnie tyle metrów mierzy budynek Viñoly'ego i tym samym tuż po realizacji stał się najwyższym budynkiem mieszkalnym na świecie. Geometryczny kształt prostopadłościanu ma proporcje wysokości do szerokości - 15:1. W tym regularnym budynku, mogącym przywoływać skojarzenia z budynkami biurowymi, mieści się aż 85 pięter, a w nich 104 apartamenty, obsługiwane przez 10 wind (Paprzyca, 2015). Dzięki umieszczeniu rezydencji mieszkalnych powyżej 61 metra wysokości, obiekt oferuje widok na zielone płuca Manhattanu (Twardowski, Żabicka, Ros Campos 2019). Smukła, biała wieża podzielona jest na 12 części, rozdzielonych dwupiętrowymi przestrzeniami otwartymi - pozwalającymi na swobodny przepływ powietrza między nimi (co ma także swoje negatywne konsekwencje techniczne). Ten podział dodaje konstrukcji dodatkowej lekkości, zwłaszcza nocą (przestrzenie podziału są inaczej podświetlone niż te mieszkalne i użytkowe).

Fasada, nowoczesna, lecz z wyraźnymi wątkami historycznymi, intryguje regularnością i trudno nie odnaleźć tu nawiązań do ortogonalnej siatki ulic Manhattanu. Wielokrotnie wspominaną inspiracją do tej charakterystycznej „kraty" miał być kosz na śmieci zaprojektowany w 1905 roku przez austriackiego architekta i projektanta - Josefa Hoffmana (jednego z twórców wiedeńskiej secesji i Wiener Werkstatte). Budynek sprawia wrażenie mocno "osadzonego" - to właśnie stabilna, regularna konstrukcja betonu. Jednocześnie czyste linie i podziały przeskalowanych okien tworzą symetryczną i klasyczną w elegancji formę. Te przeskalowane okna to nie tylko jeden z najważniejszych elementów wizualnych budowli, ale i istotny czynnik sprzedażowy i marketingowy. Doskonałe widoki i doświetlenie pozwoliły w 2014 roku is and as such, it became the tallest residential building in the world immediately upon its completion. The geometric shape of the cuboid has a height-to-basewidth ratio of 15:1. In this regular building, which can bring to mind associations with office buildings, there are eighty-five storeys with a total of 104 apartments serviced by ten lifts (Paprzyca, 2015). Due to the placement of residential spaces above the height of $61 \mathrm{~m}$, the building offers a view of Manhattan's green lung (Twardowski, Żabicka, Ros Campos, 2019). The slender, white tower is divided into twelve sections separated by two-storey open spaces-which enable the free flow of air between them (and which also has its own negative technical consequences). This division makes the structure appear lighter, especially at night (the dividing spaces are illuminated differently than residential and commercial spaces).

The facade, which is modern, but with clear historical elements, can be seen as intriguing with its regularity and it is difficult not to notice references to Manhattan's orthogonal street grid. The oft-mentioned inspiration for this distinctive 'grate' was a litter bin designed in 1905 by Austrian architect and designer Josef Hoffman (one of the founders of the Vienna Secession and the Wiener Werktstatte). The building produces an impression of being strongly 'embedded'-it is a stable, regular concrete structure. Simultaneously, the clean lines and divisions of oversized windows form a symmetrical and classically elegant form. The rescaled windows are not only one of the major visual elements of the building, but also an essential marketing and sales factor. Excellent views and insolation enabled the sale of an apartment on its ninety-sixth storey for $\$ 95$ million (Goldberger, 2014).

il. 6, 7. 111 West 57th Street (Steinway Tower), proj. SHoP Architects, 2021 r., fot. Mariusz Twardowski

ill. 6, 7. 111 West 57th Street (Steinway Tower), design by SHoP Architects, 2021, photo by Mariusz Twardowski
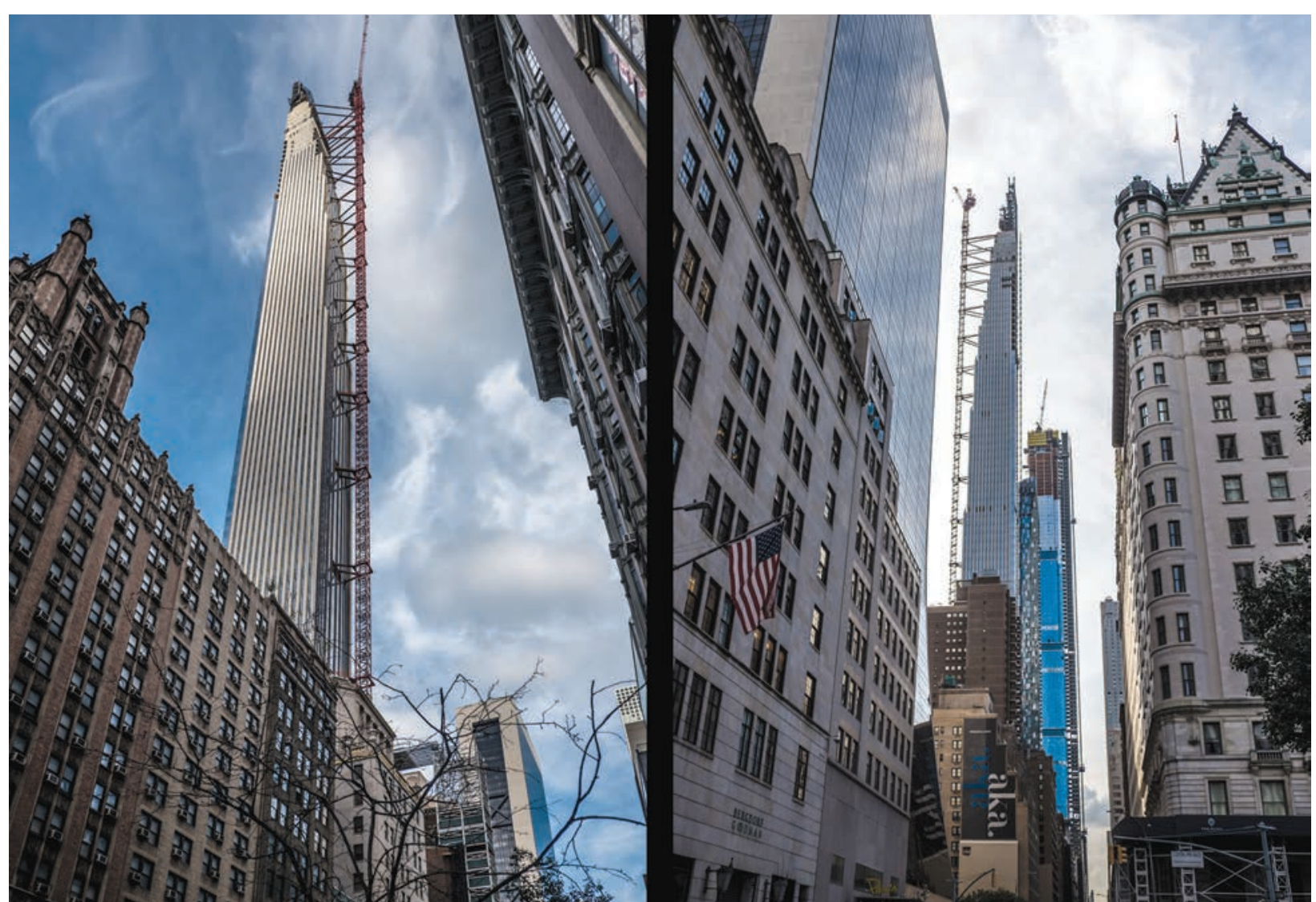
sprzedać jeden z apartamentów na 96 kondygnacji za 95 milionów dolarów (Goldberger, 2014).

432 Park Avenue to także budynek-hybryda pod kątem funkcjonalności. Zaplanowano tu liczne luksusowe apartamenty, ale i przestrzeń biurowo-konferencyjną, restaurację (z widokiem na 57th Street, czyli jedną z ważniejszych ulic Manhattanu), strefę SPA i zdrowia, basen, kluby fitness, a nawet pole do gry w golfa i winnicę.

\subsection{West 57th Street (Steinway Tower)}

Budynek został zaprojektowany w 2013 roku przez pracownię SHoP Architects. Inwestycja rozpoczęła się w 2015, pod koniec roku 2021 planowany jest odbiór budynku (Young, 2020). Nazwa budynku pochodzi od nazwiska właścicieli zlokalizowanego tu salonu sprzedaży słynnych fortepianów (Steinway\&Sons), który w trakcie budowy wieży został przeprojektowany i przebudowany. Wieża, wysoka na 435 metrów, znajduje się (to północna część 57th Street, obok Sixth Avenue) w pobliżu południowej krawędzi Central Parku i zaledwie ok. 150m od wieży One 57. 84-kondygnacyjna wieża mieszkalna jest uważana za jeden z najsmuklejszych budynków na świecie (proporcje szerokości rzutu do wysokości ok. 1:24). Górne kondygnacje cofają się, tworząc uskoki od strony południowej. To właśnie z ich powodu nowojorczycy nazywają czasem wieżę „schodami do nieba".

Budowlę wyróżnia jej ustrój konstrukcyjny. Fundamenty budynku zostały zakotwione przez 200 kotw do skał na głębokości $30 \mathrm{~m}$. To rozwiązanie pozwala na utrzymanie tak smukłego budynku w pionie. Dwie zewnętrzne, masywne ściany, o grubości do $91 \mathrm{~cm}$, utrzymując ustrój sta-
432 Park Avenue is also a hybrid building in terms of functionality. Not only does it house numerous luxury apartments, but also an office and conference space, a restaurant (with a view of 57th Street, one of Manhattan's major streets), a spa and health zone, a swimming pool, fitness spaces, and even a golf field and winery.

\subsection{West 57 th Street (Steinway Tower)}

This building was designed in 2013 by SHoP Architects. The project began in 2015, with the handover planned for late 2021 (Young, 2020). The building is named after the owners of famous piano parlour that is located here (Steinway \& Sons), which was redesigned and remodelled during the tower's construction. The tower, with a height of $435 \mathrm{~m}$, is located near the southern edge of Central Park and only $150 \mathrm{~m}$ from One 57 (Northern part of 57th Street, near Sixth Avenue). The eighty-four-storey residential tower is believed to be one of the most slender buildings in the world (the height-to-basewidth ratio is around $1: 24)$. The upper storeys are recessed, forming steps from the south. It is for this reason that New Yorkers sometimes call this tower a 'stairway to heaven'.

The building has a distinctive structural system. The foundations have been affixed by 200 anchors to bedrock at a depth of $30 \mathrm{~m}$. This solution allows the slender building to remain vertical. Two external, massive walls, with a width of $91 \mathrm{~cm}$, maintain the static system, with additional beams placed at three-storey intervals and four outrigger walls on mechanical levels (Marcus, 2015). Three
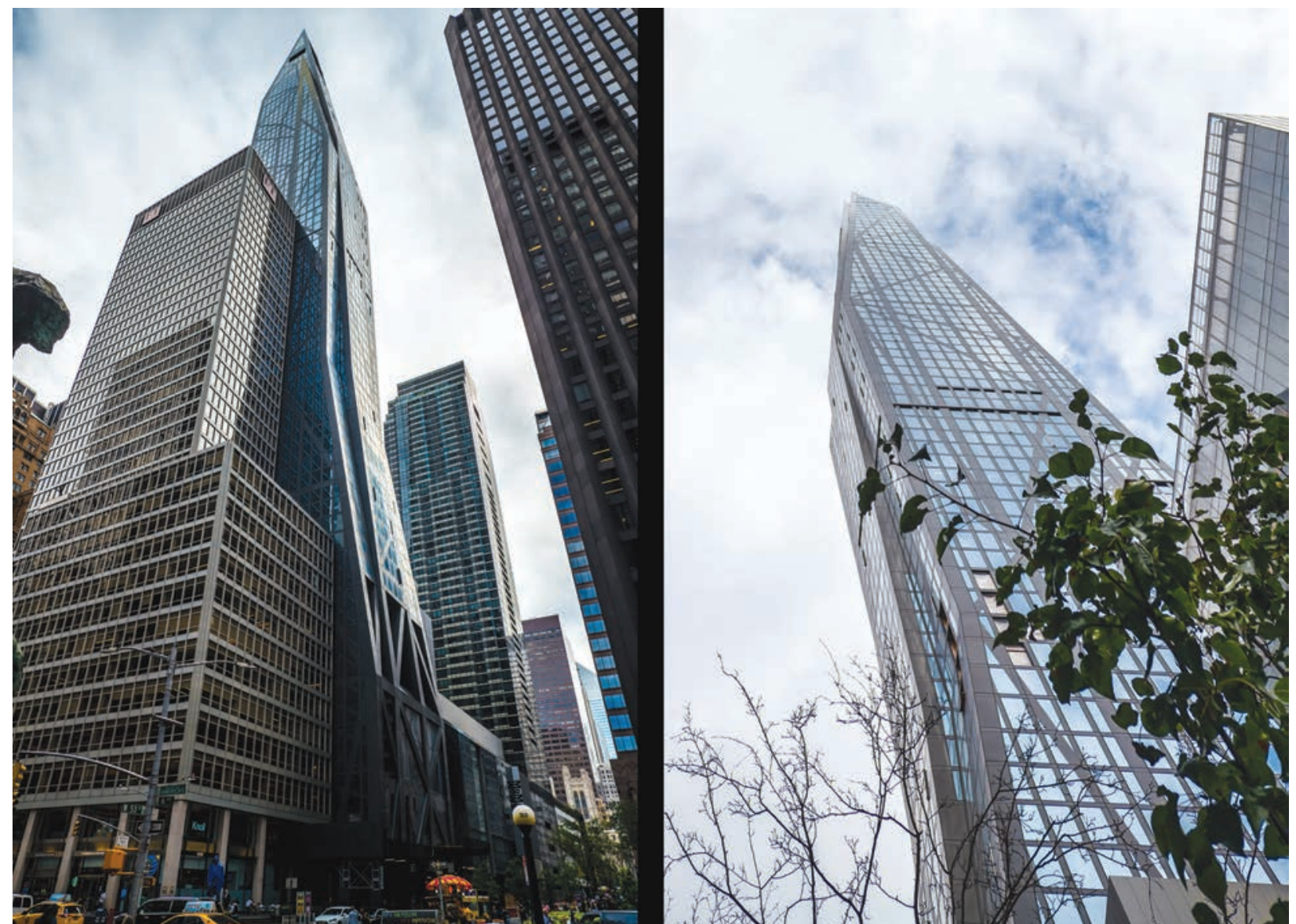
tyczny spięte są stropami i belkami co trzy kondygnacje oraz czterema ścianami na kondygnacjach technicznych (Marcus, 2015). Na trzech kondygnacjach (51, 71, 86) znajdują się wiatrochrony. Pod dachem znalazł się 800-tonowy amortyzator (dynamiczny eliminator drgań) zapewniający stabilność przy silnym wietrze lub trzęsieniach ziemi (Reid, 2019).

W budynku zlokalizowano 60 apartamentów (46 w wieży i 14 w części po budynku Steinwaya) o powierzchniach od 240 do $660 \mathrm{~m} 2$. Na trzech dolnych kondygnacjach znajdują się powierzchnie komercyjne, nieco wyżej pomieszczenia wspólne dla mieszkańców, takie jak: basen, spa, sauny, prywatne pomieszczenia jadalni $z$ aneksem kuchennym, centrum fitness i przestrzenie co-workingowe.

Podobnie, jak budynek One57, również ten budynek stał się przyczyną protestów mieszkańców obawiających się zacieniania (McKnight, 2015).

\section{4. $53 \mathrm{~W} 53$}

W wysokiej na $320 \mathrm{~m}$. wieży projektu Jeana Nouvela zaplanowano 77 nadziemnych kondygnacji użytkowych i 145 apartamentów. Wieża bywa nazywana MOMA Tower ze względu na bliskość z Museum of Modern Art. Amerykański krytyk architektury Nicolai Ouroussoff uznał, że forma budynku Nouvela jest „najbardziej ekscytującym dodatkiem naszych czasów do panoramy miasta". Elewacja zwężająca się ku górze przypomina krystaliczne szczyty poszukujące "niebiańskich wysokości". Przypomina też w pewnym sensie irracjonalność architektury gotyckiej (Ouroussoff, 2007). storeys $(51,71,86)$ feature windscreens. Under the roof there is an 800-short-ton tuned mass damper to provide stability against strong winds or earthquakes (Reid, 2019).

The building features sixty apartments (forty-six in the tower and 14 in the Steinway unit) with floor areas ranging between 240 and $660 \mathrm{~m}^{2}$. The three lowest storeys house commercial spaces, with common spaces for residents, such as a swimming pool, spas, saunas, private dining rooms with kitchenettes, a fitness centre and co-working spaces, located slightly higher.

Similarly to the One57 building, this structure has likewise become the target of protests by local residents who fear excessive shading (McKnight, 2015).

\subsection{W53}

This 320-metres-tall tower designed by Jean Nouvel is planned to house seventy-seven above-grade storeys and 145 apartments. The building is sometimes called the MOMA Tower due to its proximity to the Museum of Modern Art. American architecture critic Nicolai Ouroussoff stated that the form of Nouvel's building is the most exciting addition of our times to the city's skyline. The facade, which narrows towards the top, resembles crystalline peaks that reach for 'heavenly heights'. It also, in a sense, reminds us of the irrationality of Gothic architecture (Ouroussoff, 2007).

Apart from apartment units and a museum, the building also houses a restaurant, a cinema, a swimming pool, a fitness centre, a library with a fireplace, a playroom for children, a winery and a two-level space for social activities with kitchen facilities (Budin, 2015).

il. 10, 11. Central Park Tower, proj. Adrian Smith + Gordon Gill Architecture, 2021 r., fot. Mariusz Twardowski

ill. 10, 11. Central Park Tower, design by Adrian Smith + Gordon Gill Architecture, 2021, photo by Mariusz Twardowski

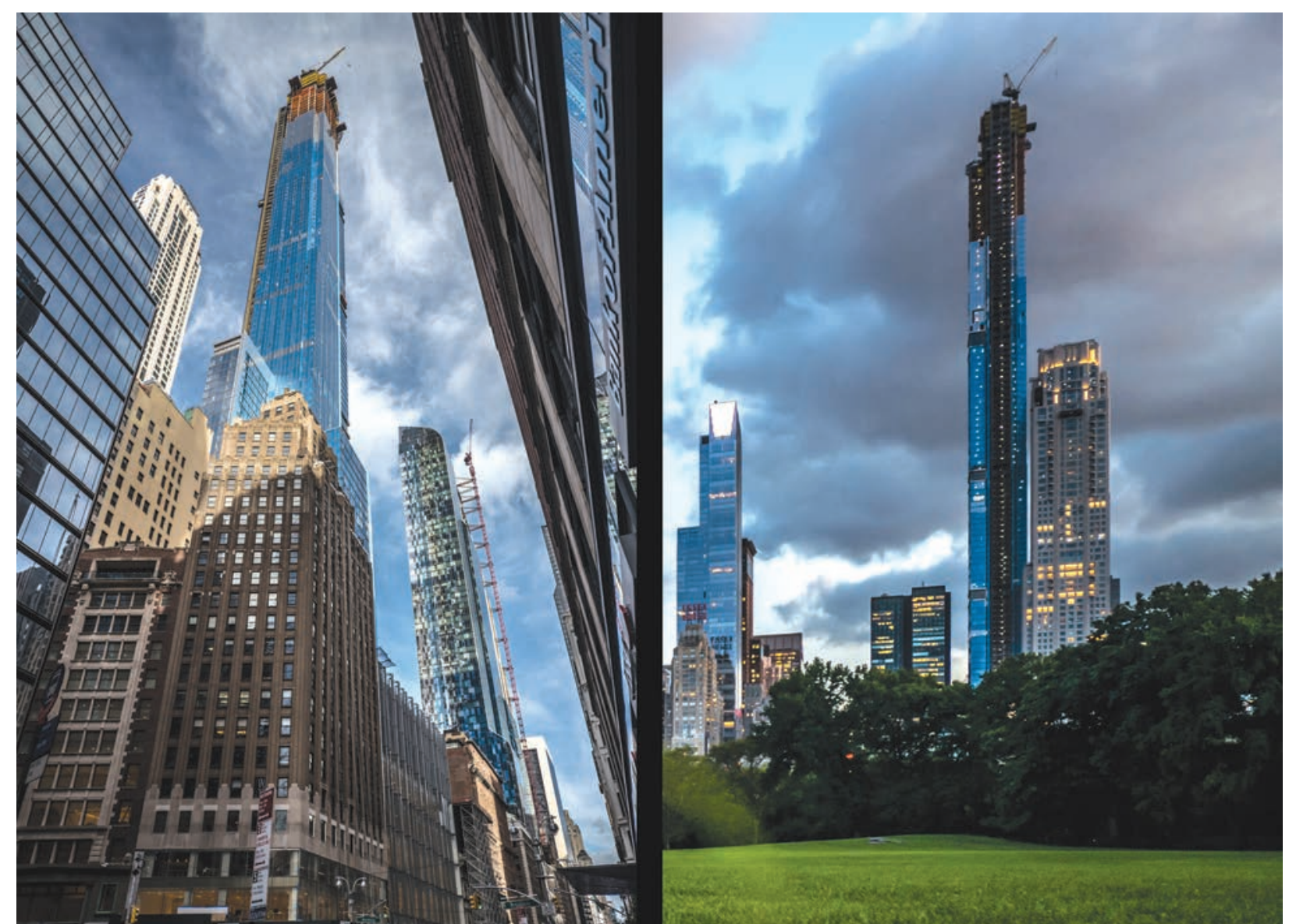


Oprócz mieszkań i muzeum znalazła się tu również restauracja, kino, basen, centrum fitness, biblioteka z kominkiem, pokój zabaw dla dzieci, winnica i dwupoziomowe pomieszczenie przeznaczone do aktywności towarzyskich z zapleczem kuchennym (Budin, 2015). Budynek jest więc niemal w pełni wyposażony i przystosowany do spędzania w nim całego czasu wolnego, stając się hybrydowym tworem wypełniającym zarówno potrzeby mieszkalne, jak i zawodowe czy społeczne. Ze względu na fakt, że współwłaścicielem wieży jest MOMA, na dolnych kondygnacjach znalazła się część muzeum (ok. $3700 \mathrm{~m}^{2}$ ). MOMA pomaga mieszkańcom rozwijać również zainteresowania artystyczne ułatwiając dostęp do swojej galerii. Właściciele apartamentów i ich goście mają nieograniczony wstęp do całej galerii (w tym indywidualne godziny oglądania dzieł sztuki), prywatne rozmowy z kuratorami wystaw, ekskluzywne pokazy filmów, wstęp na coroczny bal dobroczynny i możliwość organizowania imprez w ogrodach muzeum.

\subsection{Central Park Tower}

Wieża Central Park Tower, zaprojektowana przez Adriana Smitha i Gordona Gilla, to jedna z najnowszych inwestycji okolic Central Parku. Budowa wieży rozpoczęła się w 2014 roku, na początku 2021 r. dobiegają końca prace wnętrzarskie. Pomimo perypetii finansowych inwestora, koszt realizacji budynku wyliczono na 3 miliardy dolarów, zaś koszt sprzedaży mieszkań - 4,5 miliarda dolarów (Gourarie, 2018). Budynek znajduje się w tzw. „alei miliarderów" i, podobnie jak w przypadku sąsiednich budynków wysokościowych, również wzbudził kontrowersje wśród mieszkańców. Przyczyną protestów było zacienianie Central Parku a także budynków przy sąsiadujących ulicach.

Widoki z wieży były priorytetem podczas procesu projektowania. Elementy konstrukcyjne znalazły się więc we wnętrzu budynku. Okna otwarto od podłóg do sufitów, a narożniki budynku są przeszklone. Pod dachem znalazł się system amortyzatorów stabilizujących budynek przy wietrze. Na wysokości $91 \mathrm{~m}$. budynek został nadbudowany nad sąsiadującą budowlę dzięki wspornikowi wysuniętemu o 8,5 m. Te 8,5m stały się przyczynkiem sprawy sądowej (z inicjatywy właścicieli sąsiadującej budowli). Mimo wykupienia przez inwestora „praw do powierza", mieszkańcy starali się oprotestować (bezskutecznie) nowy budynek.

W rekordowo wysokim budynku (472m, co w 2021 roku oznacza, że jest to najwyższy budynek mieszkalny) powstało 179 mieszkań. Na siedmiu najniższych kondygnacjach zlokalizowano dom towarowy oraz hotel Central Park Club. Kolejnych 14 kondygnacji przeznaczono na przestrzeń dla mieszkańców. Są tu zatem stoły bilardowe, sale kinowe, sale wielofunkcyjne, a także zewnętrzny basen, bar, pergole i plac zabaw dla dzieci. Dwie kondygnacje powyżej to z kolei centrum SPA, wewnętrzny basen, centrum fitness, kort do squasha, sauny i łaźnie parowe.
The building is all but fully prepared and adapted for spending all of one's free time in it, becoming a hybrid creation that meets both residential, professional or social needs. Due to the fact that the MOMA is a co-owner of the tower, the lower storeys feature a section of the museum (ca. 3,700 $\mathrm{m}^{2}$ ). The MOMA aids residents in developing their artistic interests by facilitating their access to their gallery. Apartment owners and their guests have unrestricted access to the entire gallery (including dedicated art viewing hours), special access to private conversations with exhibition curators, exclusive film screenings and invitations to the annual charity ball and the possibility of organising events in the museum's gardens.

\subsection{Central Park Tower}

The Central Park Tower, designed by Adrian Smith and Gordon Gill, is one of the latest development projects from around Central Park. Construction on the tower began in 2014, with 2021 seeing the finalisation of interior finishing. Despite the developer's financial troubles, the cost of the building was calculated to be $\$ 3$ billion, while the total price of apartments- $\$ 4.5$ billion (Gourarie, 2018). The buildings is sited along Billionaires' Row and, similarly to other neighbouring tall buildings, has stirred controversy among local residents. The reason for the protest was casting shade on Central Park and buildings along neighbouring streets.

The view from the tower was a priority during design. As such, structural elements have been placed inside the building. The windows were designed to extend from floor to ceiling, while the building's corners are glazed. Under the roof there is a system of dampers that stabilise the building against wind. At a height of $91 \mathrm{~m}$, the building was extended over a neighbouring structure via an $8.5 \mathrm{~m}$ cantilever. These $8.5 \mathrm{~m}$ caused a lawsuit (filed by the owners of the neighbouring property). Despite the developer's purchase of the 'air rights', local residents protested the construction of the building (with no success).

A total of 179 apartments have been made available in this groundbreakingly tall building (its height is $472 \mathrm{~m}$, which in 2021 means that it is the tallest residential building). The seven lowest storeys house a department store and the Central Park Club Hotel. The following fourteen storeys were assigned for spaces for residents. They feature pool tables, cinemas, multifunctional spaces, as well as an external pool, a bar, pergolas and a playground for children. The two storeys above house a spa centre, an indoor pool, a fitness centre, a squash court, saunas and steam baths

The cheapest studio apartment was sold for $\$ 1.5$ million dollars. Each of the twenty largest eight-bedroom apartments was sold for $\$ 60$ million. The price of a seven-bedroom, three-level penthouse $\left(1,600 \mathrm{~m}^{2}\right.$ with a gym, ballroom, library and observatory has not been made public. The yearly cost of maintaining this apartment is $\$ 926$ thousand (Warerkar, 2017). 
Najtańsze studio zostało sprzedane za półtora miliona dolarów. Każdy z dwudziestu największych apartamentów z 8 sypialniami każdy za 60 milionów dolarów. Ceny trzypoziomowego penthausu $(1600 \mathrm{~m} 2)$ z siedmioma sypialniami, siłownią, salą balową, biblioteką, obserwatorium nie ujawniono. Koszt rocznego utrzymania tego apartamentu wynosi 926 tysięcy dolarów (Warerkar, 2017).

\section{Zagrożenia i potencjały - omówienie}

\subsection{Wieże mieszkalne jako pewne inwestycje}

Nowy Jork, podobnie jak Paryż, Rzym i Wenecja to miasto, skupiające marzenia i ambicje. Dla wielu inwestorów częścią tej ambicji jest posiadanie mieszkania na własność. Apartamenty są więc często kupowane jedynie jako forma finansowego zabezpieczenia i pozostają puste - podobnie jak najdroższe pałace nad Canal Grande w Wenecji. Rynek nieruchomości w "Wielkim Jabłku” to siła gospodarcza całego miasta. Tu znajdują się najdroższe (najwyżej wycenione) budynki na Ziemi. Za rekordowe transakcje uznaje się sprzedaż 450 Park Avenue w 2007 r. za 510 milionów dolarów (17 104 dolarów/m²) oraz 660 Madison Avenue - cena za m² wynosiła 15887 dolarów. To kwoty, które motywują kolejnych inwestorów, dla których oczywistym jest pytanie: czy możemy dodać jeszcze jedno piętro? (Twardowski, 2017)

\subsection{Negatywny wpływ wież na otoczenie}

Z perspektywy mieszkańców, realnych użytkowników budynku i okolicy wysokość wież mieszkalnych nastręcza innego rodzaju komplikacje. W przypadku budynku 423 Park Avenue i 111 West 57th Street przewidziano dodatkowe kondygnacje na wiatrochrony. W przypadku tego pierwszego jednak już pojawiły się zgłoszenia o "wyjących" windach, przeciągach i..."huśtaniu” się budynku. Zwłaszcza ta ostatnia uwaga, zgłaszana przez mieszkańców, wymaga konstruktorskich weryfikacji, ale jest to jeden z sygnałów akumulujących ryzyka związane z wysokością budynku (Pan, Tannert, Kaushik i inni, 2021).

\section{Threats and potentials-a discussion}

3.1. Residential towers as low-risk projects

New York, similarly to Paris, Rome and Venice, is a city that attracts dreams and ambitions. To many developers, having their own apartment is a part of this ambition. Apartments are thus often purchased solely as a form of financial security and remain empty-akin to the largest palaces along the Canal Grande in Venice. The property market in the Big Apple is an economic force of the entire city. It is here that the world's most expensive (valued the highest) buildings are located. The sale of 450 Park Avenue for $\$ 510$ million $\left(17,104 \$ / \mathrm{m}^{2}\right)$ in 2007 and of 660 Madison Avenue, with a price per square metre of $\$ 15,887$ are seen as record. These numbers motivate investors and developers, to whom the question whether another floor could be added is obvious (Twardowski, 2017).

3.2. Negative impact of towers on the surroundings From the perspective of residents, the actual users of the building and its neighbourhood, the height of residential towers can result in other complications. In the case of 423 Park Avenue and 111 West 57th Street, additional storeys were assigned as windscreens. In the case of the first, there have been reports of 'howling' elevators, draughts and the building itself 'rocking'. This last remark requires particular attention and verification by structural engineers, as it is a signal of accumulating risk due to the building's height (Pan, Tannert, Kaushik et al., 2021).

Another problem that has been analysed for years and associated with impressively tall residential towers is cross-ventilation and excessive wind around the buildings themselves (McGill,1983) (Zhu, Lei, Wang et al., 2020). Although it may seem impossible, both phenomena-blocking air flow and excessive air flow-can take place simultaneously at different elevations (Aristodemou, Bogangera, Mottet et al.).

il. 12. Wiatr z wirami powietrza wokół budynku 432 Park Avenue, na podstawie: Fred Mills, How Tall Buildings Tame the Wind, oprac. Mariusz Twardowski

III. 12. The whirlwind wind around 432 Park Avenue, based on: Fred Mills, How Tall Buildings Tame the Wind, ed. Mariusz Twardowski
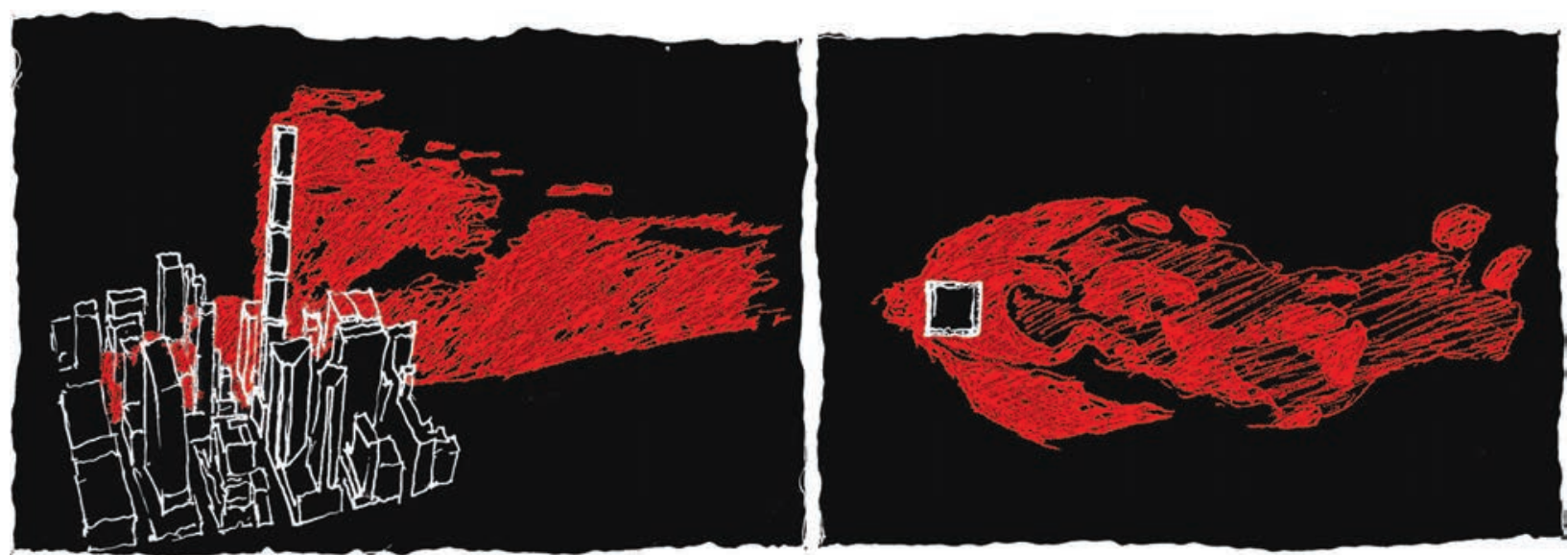


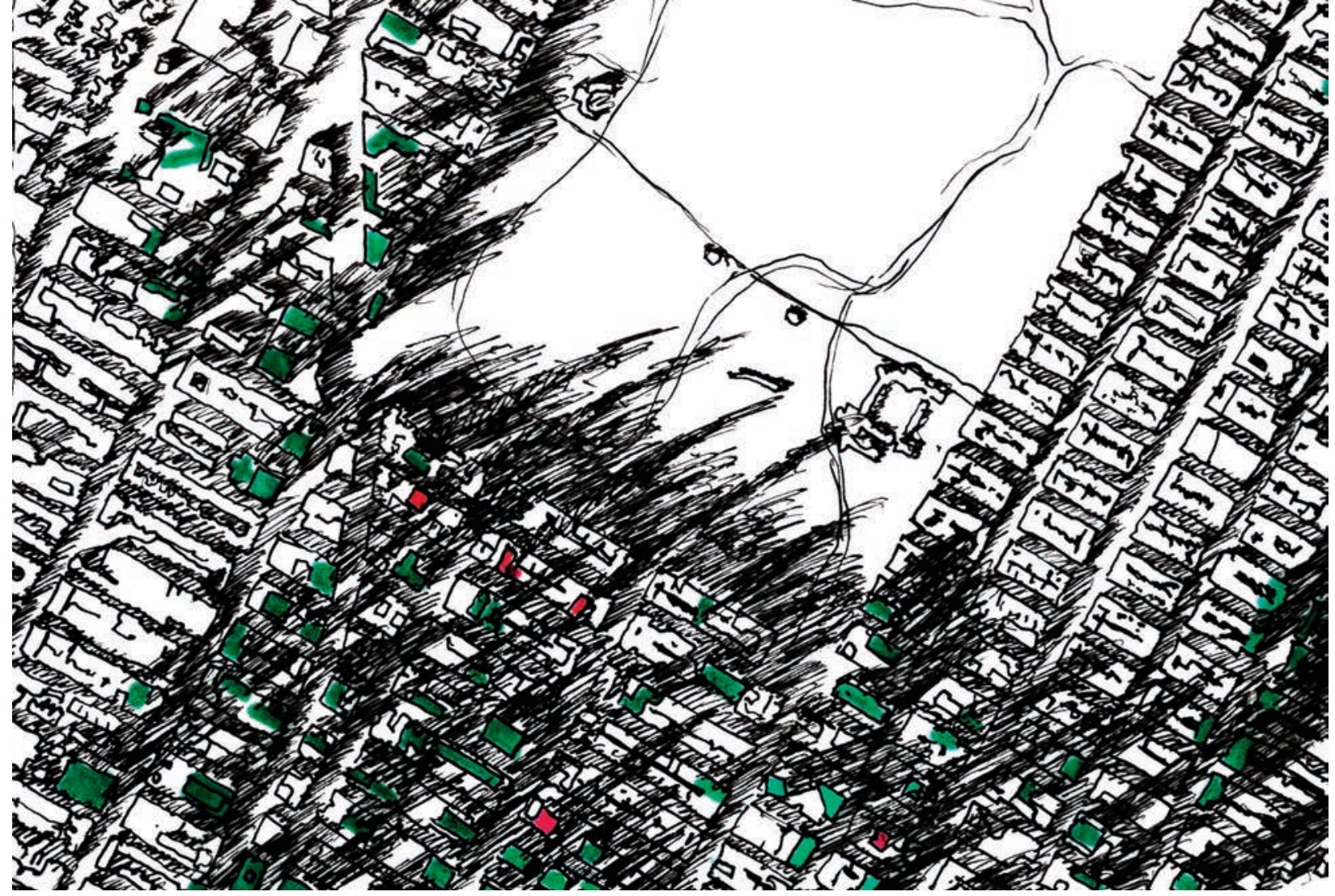

il. 13. Południowa część Central Parku i Midtown Manhattan. Zacienianie ulic, budynków i Central Parku przez coraz wyższe budowle, na podstawie: Quoctrung Bui, Jeremy White, Mapping the Shadows of New York City oprac. Mariusz Twardowski

ill. 13. South Central Park and Midtown Manhattan. Shading of streets, buildings and Central Park by taller buildings, based on: Quoctrung Bui, Jeremy White, Mapping the Shadows of New York City, ed. Mariusz Twardowski

Kolejnym problemem, analizowanym od lat (McGill,1983) (Zhu, Lei, Wang i inni, 2020), związanym z wieżami mieszkalnymi o imponujących wysokościach jest przewietrzanie i nadmierny wiatr wokół samych budynków. Choć to pozornie niemożliwe, oba zjawiska - czyli blokowanie powietrza i jego nadmierny ruch - mogą występować jednocześnie, na różnych wysokościach (Aristodemou, Boganegra, Mottet i inni). Badania wykazały, że wysokie budynki kierują ruch wiatru w dół sprawiając, że na wysokości ulic bryza czy lekki podmuch zamienia się w ciężki do zniesienia przez przechodniów bardzo silny wiatr. W Leeds zginął przechodzień przygnieciony przez przewróconą ciężarówkę w wyniku wirów mocnego wiatru utworzonych za wysokim budynkiem. ${ }^{1}$ Na Manhattanie efekt jest tym bardziej wyraźny, gdyż wysokie budynki nie pozwalają na rozbijanie i odchylanie wiatru. W górnych kondygnacjach tychże budynków mieszkańcy mocniej odczuwają wiry, które wspomagają "huśtanie" budynków. Zjawisko występuje, kiedy budynki posiadają narożniki ustawione do siebie pod kątem prostym. Rozwiązaniem jest „zmiękczanie” narożników, które sprawia, że budynki stają się bardziej aerodynamiczne, zmniejszając siły tworzonych wirów. Innym rozwiązaniem jest zmniejszanie szerokości budynków przy ich szczytach. Tak zaprojektowano 111 West 57th Street, One 57 i 53W53. Jednak kształt 432 Park Avenue nie pomaga w eliminacji zjawiska „ulicznego kanionu" (Mills, 2018).
Studies have shown that tall buildings direct wind downwards, causing a breeze or calm wind to turn into a hard-to-bear gale at street level. In Leeds, a pedestrian died after being crushed by a lorry as a result of strong air vortices created behind a tall building. ${ }^{1}$ On Manhattan, this effect is even more pronounced as tall buildings do not allow the wind to disperse or redirect. In the upper storeys of these buildings, residents experience strong vortices that compound the 'rocking' of buildings. This phenomenon takes place when buildings have corners at a right angle to one another. The solution is to 'soften' the corners, which makes buildings more aerodynamic and lowers the strength of the vortices. Another solution is to lower the width of buildings towards the top. This is how 111 West 57th Street, One 57 and 53W53 were designed. However, the shape of 432 Park Avenue does little to eliminate the phenomenon of the 'street canyon' (Mills, 2018).

Another problem created by tall buildings is shading. The residents of upper storeys have access to distant views and the sun. However, the residents of older buildings and the lower storeys of new buildings have their access to sunlight blocked. This effect is also present at street level-here pedestrians are unable to see the sun no matter the hour. Towards the end of the nineteenth and the start of the twentieth century, buildings on Manhattan were built with a narrower upper part. This solution allowed sunlight to reach the pavements. However, present-day de- 
Innym problemem tworzonym przez wysokie budynki jest zacienianie. Mieszkańcy wyższych kondygnacji posiadają dostęp do widoków i słońca. Jednak mieszkańcy starszych budynków i niższych kondygnacji nowych budynków skazani są na brak dostępu słońca. Ten efekt występuje również na ulicach - tu przechodnie nie zobaczą słońca o żadnej godzinie. Na przełomie XIX i XX wieku, na Manhattanie budowano budynki z węższą górną częścią. Takie rozwiązanie sprawiało, że słońce docierało do chodników. Tymczasem obecnie deweloperzy i architekci zapominają o problemach przechodniów. Opisywane budynki nie tylko zacieniają ulice, ale również południową część Central Parku. Internetowe wydanie The New York Times'a ma już osobną zakładkę poświęconą zacienianiu miasta przez wysokie budynki (Bui, White, 2016). Autorzy tekstów podkreślają, że wysokie budynki jak 111 West 57th Street, One 57, 432 Park Avenue czy Central Park Tower zacieniają Central Park w 1/3 swojej wielkości. Na razie zacieniają jedynie na kilka minut, ale kiedy powstanie ich więcej, cień będzie utrzymywał się przez większą część dnia.

\subsection{Wieże mieszkalne i hybrydowość funkcji}

Partery budynków to ich wizytówka, informacja, to podniesienie lub obniżenie (jeżeli jest zaniedbany) statusu całej budowli, także wież. To miejsca generujące lub blokujące ruch w danej lokalizacji. Tu tradycja sięga aż do czasów włoskich i città turrite, kiedy to w przyziemiach znajdowały się warsztaty rzemieślnicze i dawnego typu lokale gastronomiczne. Dziś najczęściej w przyziemiach pojawiają się funkcje restauracyjne i handlowe, często jednocześnie. W przypadku wież mieszkalnych, każda velopers and architects often forget about the problems of pedestrians. The buildings in question not only cast shade on the street, but also the southern part of Central Park.

The online edition of The New York Times already has a dedicated cover dedicated to the city being shaded by tall buildings (Bui, White, 2016). Article authors stress that tall buildings like 111 West 57th Street, One 57, 432 Park Avenue or Central Park Tower shade Central Park up to a third of its size. At present, they only do so for around a quarter of an hour, but when more of them are built, the shade will be present for most of the day.

\subsection{Residential towers and functional hybridity}

The ground floors are their hallmarks, an information, an enhancement or depreciation (if it is poorly maintained) of the status of an entire building, including towers. These places generate or block traffic at a given location. Here tradition dates back to Italy and its città turrite, when ground floors housed craftsmen's workshops and historical equivalents of eateries. Today, ground floors typically host restaurant and commercial uses, often simultaneously. In the case of residential towers, every function is typically assigned a separate entrance zone and vertical circulation core (and along with it: separate electrical amenities, air conditioning and plumbing). The variety of function is associated with separateness and technical safety (Twardowski, 2017).

The cases under analysis demonstrate that, apart from traditional gastronomic, commercial and hotel functions, contemporary architects often fit towers with functions that are less obvious (schools, kinder-

il. 14. Widok z łąki Sheep Meadow w Central Parku na wieżowce Manhattanu. Rok 2015. Widać pierwsze zalążki drugiego poziomu wysokich budynków. Na razie formują dwa pojedyncze "kły”, jednak za kilka lat poziom 400 m wysokości zostanie osiągnięty przez kolejnych kilka wież tworząc wysoką, pełną ścianę. fot. Mariusz Twardowski

ill. 14. View of Manhattan's skyscrapers from Sheep Meadow in Central Park, 2015. The first traces of the second level of tall buildings can be seen. At the time, they formed two solitary 'fangs', yet in a couple of years the level of $400 \mathrm{~m}$ would be achieved by several successive towers, creating a high. solid wall. Photo by Mariusz Twardowski

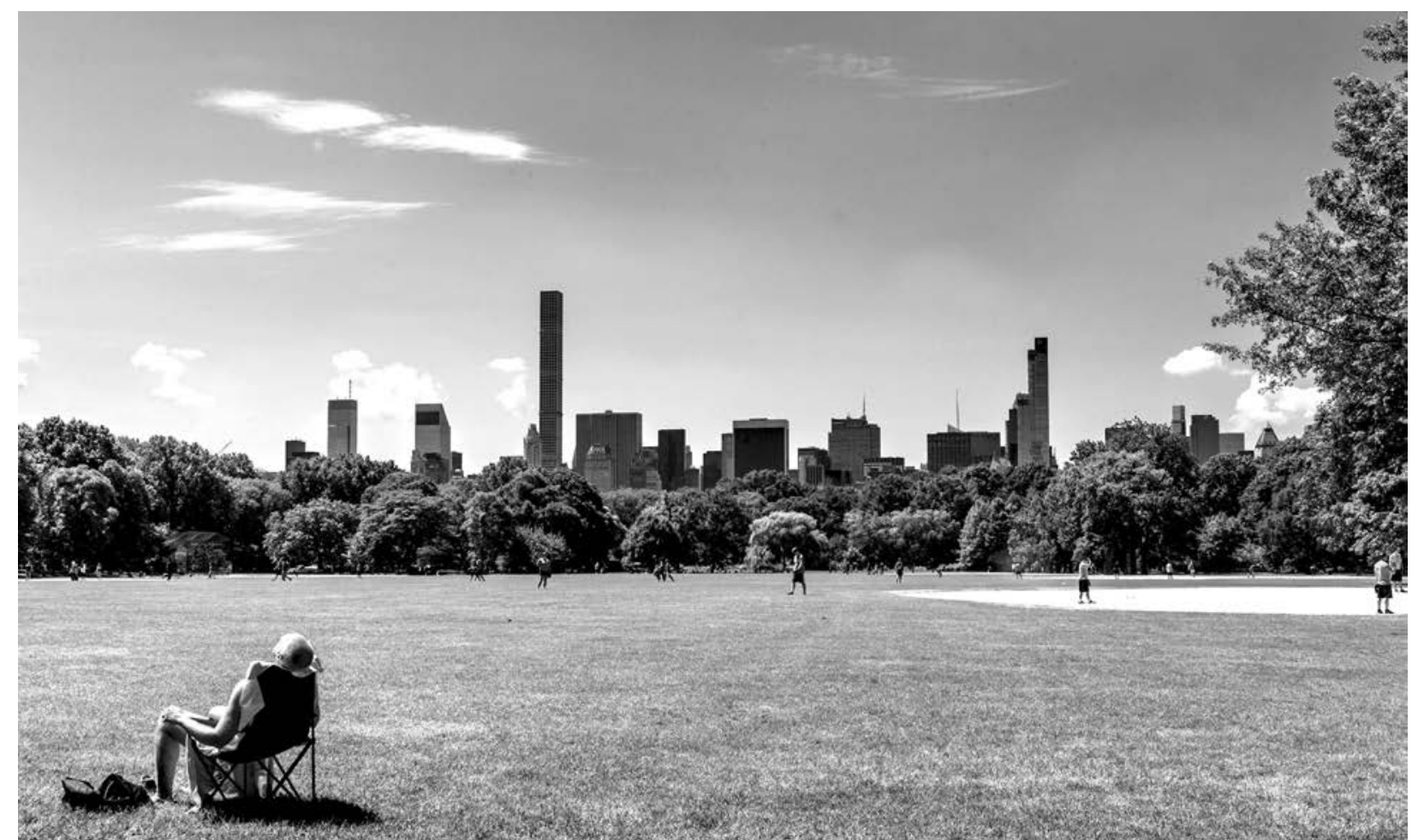


funkcja zazwyczaj otrzymuje osobną strefę wejściową i pion komunikacyjny (wraz z nim: odrębne instalacje elektryczne, klimatyzację, kanalizację). Zróżnicowanie funkcji wiąże się z rozdzielnością i bezpieczeństwem technicznym (Twardowski, 2017).

Analizowane przykłady pokazują jednak, że oprócz tradycyjnych już funkcji gastronomicznych, handlowych i hotelowych, w wieżach mieszkalnych współcześni architekci równie chętnie umieszczają funkcje mniej oczywiste jak zaplecze opiekuńczo-edukacyjne (szkoły, przedszkola, place zabaw), zdrowotne (salony spa, przychodnie), sportowe (fitness cluby, baseny) i nowoczesne lokale wspólne, będące współczesnymi wariantami dawnej agory lub przyblokowych podwórek, czyli przestrzenie co-workingowe lub jadalnie, w których można wspólnie gotować. Te nowe funkcje niekoniecznie są już umieszczane w przyziemiach, lecz na kondygnacjach wyższych, w bliższym sąsiedztwie apartamentów mieszkalnych - dzięki temu zyskują lepsze widoki z okien, a to wpływa na atrakcyjność oferowanych usług.

\subsection{Wieże mieszkalne a społeczności lokalne}

Nowojorskie wieże mieszkalne generują miejsca pracy, oszałamiające zyski i podsycają wizerunek prestiżowego miasta. Jednocześnie wzbudzają kontrowersje wśród lokalnych społeczności. Wiele z nowopowstających wież boryka się podczas procesu budowy także z protestami mieszkańców. Zauważono, że wieże mogą rzucać cień długi na 1,2 km. Architekt krajobrazu, Michael Van Valkenburgh napisał, że „światło słoneczne to radość z tego, czym jest park" (Adler, 2014). Z jego analizy wynika też, że zaciemnione przez wieże drzewa mogą umierać ok. 5 lat. To czas, po którym mieszkańcy przypiszą katastrofę drzew raczej zmianom klimatycznym niż wieżom.

Nowojorskie protesty przeciwko zacienianiu mają długą historię. "Stand Against the Shadows" to ruch zapoczątkowany w 1987, którego twarzą była Jackie Kennedy Onassis, w związku z budową Time Warner Center w miejscu New York Coliseum. Zorganizowany przez grupę marsz protestacyjny w 2015 r. miał zwrócić uwagę na problemy, które niesie realizacja wysokich budynków w przestrzeni miejskiej. Zdaniem działaczy, samo zakupienie prawa do powietrza (przestrzeni nad sąsiednim, niskim budynkiem) bez wykonania odpowiednich badań i możliwych konsekwencji środowiskowych nie powinno dawać zgody na realizację wysokiego budynku (McKnight, 2015). Problem dotyczy całego Manhattanu, jednak najbardziej jest widoczny przy południowej granicy Central Parku. To tam pojawiły się nowe wieże autorstwa gwiazd architektury: Christiana de Portzamparka, Jeana Nouvela, Rafaela Viñoly, Roberta Sterna, Adrian Smitha (dawniej SOM), SHoP Architects. To właśnie to miejsce nazywa się "Aleją miliarderów".

Grupa Stand Against the Shadows wezwała do tymczasowego wstrzymania budowy wież wyższych niż 600 stóp (183 metry). Jednym z postulatów było przeprowadzenie badań infrastrukturalnych i dostosowanie prze- gartens, playgrounds), associated with health (spa salons, healthcare centres), sports (fitness clubs, swimming pools) and modern common spaces that are contemporary variants of the historical agora or block courtyards, namely co-working spaces or dining spaces where it is possible to cook together. These new functions are not necessarily placed on ground floors, but rather in closer proximity to housing spaces-this provides them with better views, which affects the attractiveness of the services on offer.

\subsection{Residential towers versus local communities}

New York's residential towers generate jobs, overwhelming profits and enhance the image of an already prestigious city. At the same time, they cause controversy among local communities. Many newly built towers face protests from them during their construction. It has been observed that such towers can cast a shadow that is even up to $1.2 \mathrm{~km}$ long. Landscape architect Michael Van Valkenburgh wrote that 'sunlight is the joy of what a park is' (Adler, 2014). His analysis demonstrated that trees shaded by towers can die within around five years. It is a time long enough that residents could be more likely ascribe the death of a tree to climate change rather than the towers.

New York protests against shading have a long history. Stand Against the Shadows is a movement that originated in 1987 and was represented by Jackie Kennedy Onassis. It was formed in response to building the Time Warner Center at the site of the New York Coliseum. A protest march organised by the group in 2015 was to attract attention to the problems caused by building tall structures in urban space. According to the activists, the mere purchase of air rights (a right to the space above a nearby low building) without performing the necessary testing and looking at the possible environmental consequences should not give permission to construct a tall building (McKnight, 2015). This problem applies to all of Manhattan, yet it is the most visible along the southern border of Central Park. This is where new towers by starchitects Christian de Portzamparc, Jean Nouvel, Rafael Viñoly, Robert Stern, Adrian Smith (formerly of SOM) or SHoP Architects have appeared. It is the place called Billionaires' Row.

Stand Against the Shadows has called for a temporary ban on the construction of towers taller than 600 $\mathrm{ft}(183 \mathrm{~m})$. One of their postulates was to conduct infrastructural studies and adapt regulations on spatial development in terms of height and building obstacles and called for public contribution.

\section{Conclusions and summary}

Towers were and continue to be seen as New York's identifying feature. However, classical office towers are becoming a thing of the past, making way for new, mixed-use towers. As seen from this 
pisów dotyczących zagospodarowania przestrzennego w odniesieniu do wysokości i przeszkód budynków oraz zabiegało o wkład publiczny.

\section{Wnioski i podsumowanie}

Wieżowce były i są znakiem rozpoznawczym Nowego Jorku. Klasyczne biurowe wieżowce przechodzą już jednak do historii ustępując miejsca nowym, wielofunkcyjnym wieżom. Jak wynika z badań i analizy autora można obecnie wyróżnić dwa kierunki charakterystyczne dla nowych wież.

Pierwszy: funkcjonalny - budynki mieszkalne stają się hybrydami. Mieszkańcy mają do dyspozycji przestrzenie pozwalające na realizację niemal wszystkich codziennych potrzeb. W budynkach lokalizuje się zatem sklepy, restauracje, przedszkola, przestrzenie wspólne, niejednokrotnie szkoły, salony opieki zdrowotnej i spa. Miejsca zamieszkania stają się miejscami dziennego pobytu dzieci i miejscami pracy rodziców (przestrzenie co-workingowe). Drugi - budynki mieszkalne stają się coraz wyższe, często przekraczają wyśrubowane rekordy wysokości i proporcji szerokości do wysokości. Zwiększa to potencjał gospodarczy i finansowy, zarówno inwestorów jak i miasta. Jednocześnie tak wysokie budynki generują nowe wyzwania w kontekście kompozycji miasta i jego panoramy. Blokują dostęp do naturalnego nasłonecznienia niższych kondygnacji własnych i sąsiednich budynków oraz przewietrzanie. Dodatkowym zagrożeniem jest zacienianie terenów zielonych.

Tendencja wymieszania funkcji zwiększa atrakcyjność budynku dla mieszkańców i inwestorów. Rosnąca wysokość wiąże się z dodatkowymi zagrożeniami, których konsekwencje będą domagały się dalszych obserwacji.

\section{PRZYPIS}

' https://www.bbc.com/news/magazine-33426889, dostęp: 19.02.2021

\section{BIBLIOGRAFIA:}

[1] Blumenkranz, C., Gessen, K., Greif, M. red. i inni, 2008, Occupy! Sceny z okupowanej Ameryki, , Krytyka Polityczna, Warszawa 2012.

[2] Shah, J., Kothari, J., Doshi, N., 2019, A Survey of Smart City infrastructure via Case study on New York [w:] Procedia Computer Science, 160, 12019 , s. 702-705, https://doi.org/10.1016/j.procs.2019.11.024, dostęp 22.02.2021.

[3] Adler, M., 2014, New Yorkers Protest Long Shadows Cast By New Skyscrapers, https://www.npr.org/2014/04/23/305643904/nyc-s-tall-skyscrapers-cast-super-shadows-on-central-park ${ }_{\perp}$ dostęp: 08.02.2021.

[4] Goldberger, P., 2014, Too Rich, Too Thin, Too Tall? [w:] Vanity Fair https://www.vanityfair.com/culture/2014/05/condo-towers-architecturenew-york-city, dostęp: 08.02.2021

[5] vSugar, L., Kennedy, C., 2021, Urban Scaling and the Benefits of living in Cities, [w:] Sustainable Cites and Society, 66, 3 2021, https://doi. org/10.1016/j.scs.2020.102617, dostęp: 14.04.2021.

[6] Kosiński, W., 2008. Serce świata - Manhattan, Czasopismo Techniczne, 3-A/2008, 99-109.

[7] Paprzyca, K., 2015. Attractiveness of the Manhattan District, Czasopismo Techniczne, 3-A/2015, s. 143-59.

[8] Twardowski, M.; Żabicka, A., Ros Campos, A., Domy i wieże Manhattanu - miasto horyzontalne czy wertykalne?, [w:] Czasopismo Techniczne, Vol. 116, Iss. 9, Wydawnictwo Politechniki Krakowskiej, Kraków, 2019, s. 51.

[9] Young, M., 2020, 111 West 57th Street's Façade Continues To Wrap Up In Midtown [w:] New York Yimby, 30.12.2020, https://newyorkyimby.com/2020/12/111-west-57th-streets-facade-continues-to-wrapup-in-midtown.html, dostęp: 21.02.2021

[10] Reid, R. L., 2019, Skinny 'Scrapers [w:] Civil Engineering, 2019 https://www.asce.org/cemagazine/skinny-scrapers/ dostęp: 22.01.2021 study and its analyses, it is currently possible to observe two distinctive trajectories in new tower building design.

The first, functional trajectory, is based on residential buildings becoming hybrids. Residents are given spaces that can satisfy almost all of their daily needs. Buildings are designed to feature stores, restaurants, kindergartens, common spaces and sometimes even schools, spa salons and healthcare centres. Places of residence also become places of daycare for children and places of work for children (co-working spaces). The second trajectory has buildings becoming taller, often breaking extreme height and heightto-base-width ratio records. This enhances economic and financial potential, both that of investors and developers, and that of the city. At the same time, tall buildings generate new challenges in the context of city composition and that of its skyline. They block access to sunlight at lower storeys, both their own and those of neighbouring buildings, and prevent cross-ventilation. Another threat is the shading of green areas.

The tendency to mix functions increases a building's attractiveness to residents and investors. Increasing height is tied with additional threats whose consequences require further observation.

\section{ENDNOTE}

https://www.bbc.com/news/magazine-33426889, accessed: 19.02.2021

\section{REFERENCES:}

[1] Blumenkranz, C., Gessen, K., Greif, M. et al., 2008, Occupy! Sceny z okupowanej Ameryki. Krytyka Polityczna, Warszawa 2012. [2] Shah, J., Kothari, J., Doshi, N., 2019, A Survey of Smart City infrastructure via Case study on New York [in:] Procedia Computer Science, 160, 1 2019, p. 702-705, https://doi.org/10.1016/j. procs.2019.11.024, Accessed: 22.02.2021

[3] Adler, M., 2014, New Yorkers Protest Long Shadows Cast By New Skyscrapers, https://www.npr.org/2014/04/23/305643904/ nyc-s-tall-skyscrapers-cast-super-shadows-on-central-park ${ }_{\perp}$ accessed: 08.02.2021.

[4] Goldberger, P., 2014, Too Rich, Too Thin, Too Tall?, [in:] Vanity Fair, https://www.vanityfair.com/culture/2014/05/condo-towers-architecture-new-york-city, accessed: 08.02.2021.

[5] Sugar, L., Kennedy, C., 2021, Urban Scaling and the Benefits of living in Cities [in:] Sustainable Cites and Society, 66, 32021 , https://doi.org/10.1016/j.scs.2020.102617_accessed: 14.04.2021.

[6] Kosiński, W., 2008. Serce świata - Manhattan, Czasopismo Techniczne, 3-A/2008, 99-109.

[7] Paprzyca, K., 2015. Attractiveness of the Manhattan District, Czasopismo Techniczne, 3-A/2015, pages 143-59.

[8] Twardowski, M.; Zabicka, A., Ros Campos, A., Domy i wieże Manhattanu - miasto horyzontalne czy wertykalne? [in:] Czasopismo Techniczne, Vol. 116, Iss. 9, Wydawnictwo Politechniki Krakowskiej, Kraków, 2019, p. 51.

[9] Young, M. 2020, 111 West 57th Street's Façade Continues To Wrap Up In Midtown [in:] New York Yimby, 30.12.2020, https:// newyorkyimby.com/2020/12/111-west-57th-streets-facade-continues-to-wrap-up-in-midtown.html, accessed: 21.02.2021

[10] Reid, R. L., 2019, Skinny 'Scrapers [in:] Civil Engineering, 2019 https://www.asce.org/cemagazine/skinny-scrapers/, accessed: 22.01.2021

[11] McKnight, J., 2015. Wave of super-tall towers in Manhattan sparks protests over shadows [in:] Dezeen, 11.11.2015, https:// www.dezeen.com/2015/11/11/supertall-skinny-skyscrapers-towers-manhattan-new-york-shop-architects-robert-stern-rafaely-vinoly-jean-nouvel-portzamparc-controversy-protest/, accessed: 01.02.2021

[12] Ouroussoff, N., 2007, Next to MoMA, a Tower Will Reach for the Stars [in:] The New York Times, https://www.nytimes. com/2007/11/15/arts/design/15arch.html, accessed: 15.02.2021 
[11] McKnight, J., 2015, Wave of super-tall towers in Manhattan sparks protests over shadows [w:] Dezeen, 11.11.2015, https://www.dezeen.com/2015/11/11/ supertall-skinny-skyscrapers-towers-manhattan-new-york-shop-architects-robert-stern-rafaely-vinoly-jean-nouvel-portzamparc-controversy-protest/ dostęp: 01.02 .2021

[12] Ouroussoff, N., 2007, Next to MoMA, a Tower Will Reach for the Stars [w: The New York Times, https://www.nytimes.com/2007/11/15/arts/design/15arch. html, dostęp: 15.02.2021

[13] Budin, J. 2015 Multimillion-Dollar MoMA Condos Come With Museum Perks [w:] Curbed New York, https://ny.curbed.com/2015/6/18/9948584/multimillion-dollar-moma-condos-come-with-museum-perks, dostęp: 12.02.2021

14] Gourarie, C., 2018, Barnett closes on \$1B-plus financing for Central Park Tower [w:] The Real Deal, https://therealdeal.com/2018/01/01/barnett-closeson-1b-financing-for-central-park-tower/, dostęp: 20.02.2021

[15] Warerkar, T., 2017, Central Park Tower's sprawling floorplans, exorbitant prices are unveiled [w:] Curbed New York, https://ny.curbed.com/2017/7/7/15933586/ central-park-tower-floorplans-pricing, dostęp: 18.02.2021

[16] Twardowski, M., 2017. Wieże mieszkalne, Monografia, Wydawnictwo Politechniki Krakowskiej, Kraków 2017 r., s. 44.

17] Pan, Y. Tannert, T. Kaushik, K i inni, Seismic performance of a proposed wood-concrete hybrid system for high-rise buildings [w:] Engineering Structures, 238, 7 2021, https://doi.org/10.1016/j.engstruct.2021.112194 dostęp: 23.05.2021.

[18] McGill, D. C. 1983, With skyscrapers, a windy day is windier, https://www. nytimes.com/1983/12/08/nyregion/with-skyscrapers-a-windy-day-is-windier.html , dostęp: 19.02.2021

[19] Zhu, Z., Lei, W., Wang, Q., i inni, 2020, Study on wind-induced vibration control of linked high-rise buildings by using TMD/ [w:] Journal of Wind Engineering and Industrial Aerodynamics, 205, 10 2020, https://doi.org/10.1016/j. jweia.2020.104306 dostęp: 12.03.2021.

[20] Aristodemou, E., Boganegra, L.M., Mottet, L. i inni, 2018. How tall buildings affect turbulent air flows and dispersion of pollution within a neighbourhood [w: Environmental Pollution, Volume 233, February 2018, s. 782-796, https://doi org/10.1016/j.envpol.2017.10.041, Dostęp: 18.02.2021

21] Mills, F. 2018, How Tall Buildings Tame the Wind [w:] The B1M, 12.12.2018, https://www.theb1m.com/video/how-tall-buildings-tame-the-wind, dostęp 25.02.2021

[22] Bui, Q., White, J., 2016, Mapping the Shadows of New York City: Every Building, Every Block [w:] The New York Times, https://www.nytimes.com/interactive/2016/12/21/upshot/Mapping-the-Shadows-of-New-York-City.html, dostęp: 28.02.2021

\section{ŹRÓDŁA INTERNETOWE:}

https://www.bbc.com/news/magazine-33426889, dostęp: 19.02.2021
13] Budin, J., 2015, Multimillion-Dollar MoMA Condos Come With Museum Perks [in:] Curbed New York, https://ny.curbed. com/2015/6/18/9948584/multimillion-dollar-moma-condos-come-with-museum-perks, accessed: 12.02 .2021

[14] Gourarie, C. 2018, Barnett closes on \$1B-plus financing for Central Park Tower [in:] The Real Deal, https://therealdeal. com/2018/01/01/barnett-closes-on-1b-financing-for-central-park-tower/, accessed: 20.02.2021

[15] Warerkar, T., 2017, Central Park Tower's sprawling floorplans, exorbitant prices are unveiled [in:] Curbed New York, https://ny.curbed.com/2017/7/7/15933586/central-park-tower-floorplans-pricing, accessed: 18.02.2021

[16] Twardowski, M., 2017. Wieże mieszkalne, Monografia, Wydawnictwo Politechniki Krakowskiej, Kraków 2017 r., p. 44. [17] Pan, Y., Tannert, T., Kaushik, K., i inni, Seismic performance of a proposed wood-concrete hybrid system for high-rise buildings [in:] Engineering Structures, 238, 7 2021, https://doi. org/10.1016/j.engstruct.2021.112194, accessed: 23.05.2021. [18] McGill, D. C., 1983, With skyscrapers, a windy day is windier $\quad$ https://www nytimes.com/1983/12/08/nyregion/ with-skyscrapers-a-windy-day-is-windier.html, accessed: 19.02.2021.

[19] Zhu, Z., Lei, W., Wang, Q., et al., 2020, Study on wind-induced vibration control of linked high-rise buildings by using TMD/ [in:] Journal of Wind Engineering and Industrial Aerodynamics, 205, 10 2020, https://doi.org/10.1016/j. jweia.2020.104306, accessed: 12.03.2021.

[20] Aristodemou, E., Boganegra, L.M. Mottet, L. et al., 2018. How tall buildings affect turbulent air flows and dispersion of pollution within a neighbourhood, [in:] Environmental Pollution, Volume 233, February 2018, pp. 782-796, https://doi. org/10.1016/j.envpol.2017.10.041, accessed: 18.02.2021.

[21] Mills, F., 2018, How Tall Buildings Tame the Wind [in:] The B1M, 12.12.2018, https://www.theb1m.com/video/how-tall-buildings-tame-the-wind, accessed: 25.02.2021

[22] Bui, Q., White, J., 2016, Mapping the Shadows of New York City: Every Building, Every Block [in:] The New York Times, https://www.nytimes.com/interactive/2016/12/21/ upshot/Mapping-the-Shadows-of-New-York-City.html, accessed: 28.02.2021.

\section{ONLINE SOURCES:}

https://www.bbc.com/news/magazine-33426889, accessed: 19.02.202 